\title{
Sistem Pendukung Keputusan Pemilihan Mobil Rental dengan Menggunakan Metode Topsis (Studi Kasus : CV. Bita Jaya Mandiri)
}

\author{
Sri Mandakini \\ STMIK Budi Darma Medan, Jl.Sisingamangaraja No.338 Simpang Limun Medan, Indonesia \\ sri.mandakini@gmail.com
}

\begin{abstract}
Abstrak. Seiring dengan perkembangan era permintaan, untuk selalu cepat dalam melakukan segala hal, saya tidak mungkin dihindari dari yang namanya transportasi. Transportasi merupakan kebutuhan semua orang hidup. Mobil adalah salah satu dari transportasi darat negosiasi yang dipilih oleh orang-orang. Orang yang bekerja dibidang jasa memilik berbagai jenis mobil untuk memenuhi kebutuhan masyarakat. Untuk mendapatkan mobil yang sesuai dengan harapan, tentu saja, penyewa rental/pemilik rental mobil harus memiliki informasi tentang mobil. Dari banyak mobil pilihan kita dapat membuat keputusan dengan mengandalkan perasaan. Namun, kami memiliki kesulitan dalam membuat keputusan. Oleh karena itu diperlukan suatu sistem pendukung keputusan untuk membantu konsumen memutuskan mobil yang akan disewa berdasarkan kriteria yang dia inginkan. TOPSIS merupakan salah satu metode yang dapat digunakan dalam proses pengambilan keputusan. Dan prodok yang digunakan adalah produk Mobil Toyota tahun 2000-2014. Metode ini dapat digunakan untuk menentukan apakah mobil akan disewa sesuai dengan kualifikasi yang dibutuhkan atau tidak. Hal ini karena metode sebuah langkah-langkah untuk bisa memberikan penilaian, baik kualitatif dan kuantitatif. Dan TOPSIS merupakan metode dalam mengambil memperhitungkan batas toleransi validitas berbagai kriteria dipilih oleh pembuat keputusan.
\end{abstract}

Kata Kunci : Sistem Pendukung Keputusan, Technique for Order Preferency by Similarity Ideal Solution (TOPSIS), Mobil Rental.

\begin{abstract}
Along with the development of the era of demand, to always be fast in doing everything, I can't be avoided from the name of transportation. Transportation is a necessity for everyone alive. The car is one of the negotiated land transportation that is chosen by the people. People who work in the service sector own various types of cars to meet the needs of society. To get a car that meets expectations, of course, the rental tenant / car rental owner must have information about the car. Of the many car choices we can make decisions based on feelings. However, we had difficulty making a decision. Therefore we need a decision support system to help consumers decide which car to rent based on the criteria they want. TOPSIS is a method that can be used in the decision making process. And the products used are Toyota Cars 2000-2014. This method can be used to determine whether the car will be rented according to the qualifications required or not. This is because the method is a step-by-step assessment, both qualitative and quantitative. And TOPSIS is a method of taking into account the tolerance limits for the validity of various criteria chosen by the decision maker.
\end{abstract}

Keyword : Decision Support Systems, Technique for Order Preference by Similarity Ideal Solution (TOPSIS), Car Rental.

\section{PENDAHULUAN}

Mobil merupakan alat transportasi yang digunakan oleh manusia untuk melaksanakan segala aktifitasnya dan tidak jarang dianggap sebagai kebutuhan pokok. Mobil adalah salah satu contoh kendaraan yang umum digunakan dan dianggap sebagai kebutuhan pokok. Pada saat ini jenis mobil begitu banyak dari berbagai merk dan jenis. Setiap jenis mobil memiliki spesifikasi teknis yang berbeda, dan setiap mobil pastinya memiliki kelebihan dan kekurangan. Dan hal ini, akan mengakibatkan para calon atau konsumen mengalami kesulitan untuk memilih mobil yang tepat dan sesuai dengan kriteria yang diinginkan dikarenakan calon penyewa dihadapkan pada banyaknya kriteria [1], [2].

Sejalan dengan perkembangan teknologi informasi yang ada, komputer semakin bertambah kemampuannya untuk membantu menyelesaikan permasalahan, salah satunya adalah membantu dalam pengambilan keputusan. Sistem Pendukung Keputusan adalah suatu pengakhiran dari proses 
pemikiran tentang suatu masalah atau problem untuk menjawab pertanyaan guna mengatasi masalah tersebut[3].

Sistem ini dirancang untuk membantu calon penyewa mengambil keputusan dalam pemilihan kendaraan, khususnya mobil sehingga keputusan yang diperoleh sesuai dengan kriteria yang diinginkan. Dan metode yang digunakan untuk pengambilan keputusan ini adalah Metode Technique for Order Preference by Similarity to Ideal Solution (TOPSIS) yang merupakan suatu metode pemberian urutan (prioritas) dalam analisis multikriteria. Technique Order Pirefirence By Similarity To Ideal Solution (TOPSIS) merupakan bagian dari konsep Multi-Attribut Decison Making (MADM) dimana diperlukan normalisasi pada perhitungannya. Dengan menggunakan metode Technique Order Pirefirence By Similarity To Ideal Solution (TOPSIS), di harapkan dapat dikembangkan software sistem pendukung keputusan yang dapat digunakan oleh suatu instansi, Adapun tujuan dari penelitian adalah untuk merancang suatu sistem pengambilan keputusan dengan menggunakan metode TOPSIS[4], [5], sehingga dapat membantu calon penyewa untuk memilih kendaraan sesuai dengan kriteria yang diinginkan[6].

Adapun yang menjadi batasan masalah pada penelitian ini adalah kriteria-kriteria yang digunakan yaitu harga sewa mobil, bahan bakar, kenyamanan mobil, kapasitas muatan, dan tahun pembuatan, sistem pengambilan keputusan pemilihan mobil rental ini khususnya mobil merk Toyota seperti Mobil Avanza, Kijang Inova, Xenia, Agya dan Yaris. Dan hanya membahas sewa rental / per hari, Metode yang digunakan Technique Order Pirefirence By Similarity To Ideal Solution (TOPSIS) dan Produk tahun pembuatan mobil yang digunakan sebagai data adalah mobil produksi tahun 2000 -2014 dan produk tersebut telah diedarkan di pasar Indonesia.

Manfaat dari penelitian ini adalah sebagai sistem yang akan dibangun diharapkan dapat memberikan manfaat kemudahan kepada penyewa mobil agar dapat menentukan mobil yang akan mau disewa selanjutnya CV. Bita Jaya Mandiri memberikan mobil yang ingin disewa sesuai keinginan konsumen, dan dapat membantu proses pengambilan keputusan dengan seefektif mungkin dengan adanya kriteria yang telah ada.

\section{METODOLOGI PENELITIAN}

\subsection{Sistem Pendukung Keputusan}

Pengambilan keputusan (decision making) memegang peranan yang sangat penting karena keputusan yang diambil oleh manager merupakan hasil pemikiran akhir yang harus dilaksanakan oleh bawahannya atau mereka yang bersangkutan dengan organisasi yang di pimpin. Pengambilan keputusan adalah bagian kunci kegiatan manajer, dan suatu proses pemikiran dalam rangka pemecahan suatu masalah untuk memperoleh hasil akhir untuk dilaksanakan[7].

\subsection{Karakteristik Sistem Pendukung Keputusan}

Dari pengertian Sistem Pendukung Keputusan maka dapat ditentukan karakteristik antara lain[8]:

1. Komponen Sistem (components)

2. Batasan Sistem (boundary)

3. Lingkungan Luar Sistem (Environment)

4. Penghubungan Sistem (interface)

5. Masukan Sistem (input)

\subsection{Keuntungan Sistem Pendukung Keputusan}

Beberapa keuntungan penggunaan SPK antara lain adalah sebagai berikut [9]:

1. Mampu mendukung pencarian solusi dari berbagai permasalahan yang kompleks.

2. Dapat merespon dengan cepat pada situasi yang tidak diharapkan dalam kondisi yang berubahubah. 
3. Mampu untuk menerapkan berbagai strategi yang berbeda pada konfigurasi berbeda secara cepat dan cepat.

4. Pendangan dan pembelajaran baru.

5. Sebagai fasilitator dalam komunikasi.

6. Meningkatkan kontrol manajemen dan kenerja.

7. Menghemat biaya dan sumber daya manusia (SDM).

\subsection{Kelemahan Sistem Pendukung Keputusan}

Adapun kelemahan yang dimiliki sistem pendukung keputusan adalah:

1. Ada beberapa kemampuan manajemen dan bakat manusia yang tidak dapat dimodelkan, sehingga model yang ada dalam sistem tidak semuanya mencerminkan persoalan sebenarnya.

2. Kemampuan suatu SPK terbatas pada perbendaharaan pengetahuan yang dimilikinya (pengetahuan dasar dan serta model dasar).

3. Proses-proses yang dapat dilakukan SPK biasanya juga tergantung pada perangkat lunak yang digunakan.

4. SPK tidak memiliki kemampuan intuisi seperti yang dimiliki manusia.Sistem ini dirancang hanya untuk membantu pengambil keputusan dalam melaksanakan tugasnya.

\subsection{Fuzzy Multi Attribute Decision Making (FMADM)}

Fuzzy Multi Attribute Decision Making (FMADM) adalah suatu metode yang digunakan untuk mencari alternatif optimal dari sejumlah alternatif dengan kriteria tertentu. Inti dari FMADM adalah menentukan nilai bobot untuk setiap atribut, kemudian dilanjutkan dengan proses perengkingan yang akan menyeleksi alternatif yang sudah diberikan.

Pada dasarnya, ada tiga pendekatan untuk mencari nilai bobot atribut, yaitu pendekatan subyektif, pendekatan obyektif dan pendekatan integrasi anatara subyektif dan obyektif. Masingmasing pendekatan memiliki kelebihan dan kelemahan. Pada pendekatan subyektif, nilai bobot ditentukan berdasarkan subyektifitas dari para pengambil keputusan, sehingga beberapa faktor dalam proses perengkingan alternatif dapat ditentukan secara bebas. Sedangkan pada pendekatan obyektif, nilai bobot dihitung secara matematis sehingga mengabaikan subyektifitas dari pengambil keputusan[10].

Ada beberapa metode yang dapat digunakan untuk menyelesaikan masalah FMADM antara lain[11]:

1. Simple Additive Weighting (SAW)

2. Weighted Product (WP)

3. ELECTRE

4. Technique for Order Preference by Similarity to Ideal Solution (TOPSIS)

5. Analitic Hierarchy Process (AHP).

\subsection{Algoritma Fuzzy Multi Attribute Decision Making (FMADM)}

Algoritma Fuzzy Multi Attribute Decision Making[12], adalah :

1. Memberikan nilai setiap alternatif $\left(\mathrm{A}_{\mathrm{i}}\right)$ pada setiap kriteria $\left(\mathrm{C}_{\mathrm{j}}\right)$ yang sudah ditentukan, dimana nilai tersebut diperoleh berdasarkan nilai crisp; $\mathrm{i}=1,2, \ldots \mathrm{m}$ dan $\mathrm{j}=1,2, \ldots \mathrm{n}$.

2. Menentukan nilai bobot (W) yang juga didapatkan berdasarkan nilai crisp.

3. Melakukan normalisasi matriks dengan cara menghitung nilai reting kinerja ternormalisasi $\left(\mathrm{r}_{\mathrm{ij}}\right)$ dan alternatif $\left(\mathrm{A}_{\mathrm{i}}\right)$ pada atribut $\left(\mathrm{C}_{\mathrm{j}}\right)$ berdasarkan persamaan yang disesuaikan dengan jenis atribut (atribut keuntungan $/$ benefit $=$ Maksimum atau atribut biaya $/$ cost $=$ Minimum). Apabila berupa atribut keuntungan maka nilai crisp $\left(\mathrm{X}_{\mathrm{ij}}\right)$ dari setiap kolom atribut dibagi dengan nilai crisp MAX $\left(\right.$ MAX $\mathrm{X}_{\mathrm{ij}}$ ) dari setiap kolom, sedangkan untuk atribut biaya, nilai crisp MIN (MIN $\mathrm{X}_{\mathrm{ij}}$ ) dari setiap kolom atribut dibagi dengan nilai crisp $\left(X_{i j}\right)$ setiap kolom. 
4. Melakukan proses perengkingan dengan cara mengalihkan matriks ternormalisasi (R) dengan nilai bobot (W).

5. Melakukan nilai preferensi untuk setiap alternatif $\left(\mathrm{V}_{\mathrm{i}}\right)$ dengan cara menjumlahakan hasil kali antara matriks ternormalisasi (R) dengan nilai bobot $(\mathrm{W})$. Nilai $\mathrm{V}_{\mathrm{i}}$ yang lebih besar mengindikasikan bahwa alternatif lebig terpilih. (Sri Kusuma Dewi, 2006)

\subsection{TOPSIS (Technique for Order Preference by Similarity to Ideal Solution)}

Pada dasarnya, proses pengambilan keputusan adalah memilih suatu alternatif. Menurut Hwang dan Yoon dalam TOPSIS (Technique for Order Preference by Similarity to Ideal Solution) didasarkan pada konsep dimana alternatif tepilih yang terbaik tidak hanya memiliki jarak terpendek dari solusi ideal positif, namun juga memiliki jarak terpanjang dari solusi ideal negatif

Menurut Hwang, Liang dan Yeh dalam, konsep ini banyak digunakan pada beberapa model MADM (Multi Attribute Decision Making) untuk menyelesaikan masalah keputusan secara praktis. Hal ini disebabkan konsepnya sederhana, mudah dipahami, komputasinya efesien, dan memiliki kemampuan untuk mengukur kinerja relatif dari alternatif-alternatif keputusan dalam bentuk matematis yang sederhana. Berikut adalah langkah-langkah dari metode TOPSIS[13]:

1. TOPSIS dimulai dengan membangun sebuah matriks keputusan.

Matriks keputusan X mangacu terhadap m alternatif yang akan dievaluasi berdasarkan $\mathrm{n}$ kriteria. Matriks keputusan $\mathrm{X}$ dapat dilihat pada gambar di bawah ini.

$$
r_{i j}=\frac{X_{i j}}{\sqrt{\sum_{i}^{m} X_{i j}^{2}}}
$$

2. Membuat solusi ideal positif dan solusi ideal negatif

Persamaan yang digunakan untuk dapat menentukan solusi ideal positif dan solusi negatif dapat ditentukan berdasarkan rating bobot ternormalisasi $\left(\mathrm{y}_{\mathrm{ij}}\right)$ :

$\mathrm{y}_{\mathrm{ij}}=\mathrm{W}_{\mathrm{i}} \mathrm{r}_{\mathrm{ij}}$

Dengan $\mathrm{i}=1,2, \ldots, \mathrm{m} ;$ dan $\mathrm{j}=1,2, \ldots, \mathrm{n}$.

$A^{+}=\left(y_{1}^{+}, y_{2}^{+}, \ldots, y_{n}^{+}\right)$;

$A^{-}=\left(y_{1}^{-}, y_{2}^{-}, \ldots, y_{n}^{-}\right)$;

Dengan

$y_{j}^{+}=\left\{\begin{array}{l}\max _{\bar{i}} y_{i j} ; j i k a, \mathrm{j} \text { adalah atribut keuntungan } \\ \min _{i} y_{i j} ; j i k a \mathrm{j} \text { adalah atribut biaya }\end{array}\right.$

$y_{j}^{-}=\left\{\begin{array}{l}\min _{i} y_{i j} ; j i k a j \text { adalah atribut keuntungan } \\ \max _{i} y_{i j} ; j i k a j \text { adalah atribut biaya }\end{array}\right.$

3. Membuat jarak antar alternatif $A_{i}$ dengan solusi ideal positif yang dirumuskan sebagai berikut: $D_{i}^{+}=\sqrt{\sum_{j=i}^{n}\left(y_{i}^{+}-y_{i j}\right)^{2}}$

4. Membuat jarak anatara alternatif $A_{i}$ dengan solusi ideal negatif dirumuskan sebagai berikut: $D_{i}^{-}=\sqrt{\sum_{j=i}^{n}\left(y_{i j}-y_{i}^{-}\right)^{2}}$

5. Menentukan nilai preferensi untuk setiap alternatif yang dirumuskan sebagai berikut :

$$
V_{i}=\frac{D_{i}}{D_{i}^{-}+D_{i}^{+}}
$$


6. Merangking Alternatif

Alternatif diurutkan dari nilai $\mathrm{V}_{\mathrm{i}}$ terbesar ke nilai terkecil. Alternatif dengan nilai $\mathrm{V}_{\mathrm{i}}$ terbesar merupakan solusi yang terbaik (Pelita Informatika Budi Darma,Volume III Nomor : 2 , April 2013,ISSN : 2301-9425).

\section{HASIL DAN PEMBAHASAN}

Dalam membangun sistem pendukung keputusan rekomendasi pemilihan mobil rental menggunakan metode TOPSIS diperlukan data sebagai berikut :

1. Data Kriteria

Harga Sewa Rental, Bahan bakar, Kenyamanan, Kapasitas Muatan, dan Tahun Pembuatan.

2. Data Bobot

Data bobot kriteria akan ditentukan dengan jumlah semua bobot kriteria sama dengan 100 . Adapun tabel bobot kriteria sebagai berikut :

Tabel 1. Bobot kriteria

\begin{tabular}{|l|c|}
\hline \multicolumn{1}{|c|}{ Alternatif } & Nilai bobot kriteria \\
\hline Harga Sewa Mobil & 20 \\
\hline Bahan Bakar & 25 \\
\hline Kenyamanan & 30 \\
\hline Kapasitas Muatan & 15 \\
\hline Tahun Pembuatan & 10 \\
\hline \multicolumn{1}{|c|}{ Total } & 100 \\
\hline
\end{tabular}

3. Data Nilai Kriteria

Data nilai kriteria untuk rekomendasi pembelian perumahan yang dimasukan oleh user berkisar antara 1 sampai 5 dengan ketentuan :
a. 1 = Sangat buruk
b. $2=$ Buruk
c. $3=$ Cukup
d. $4=$ Baik
e. 5 = Sangat baik

Model FMADM dan Topsis dalam prosesnya memerlukan kriteria yang akan dijadikan bahan perhitungan pada proses perangkingan. Kriteria yang menjadi bahan pertimbangan pada rekomendasi pembelian perumahan seperti yang ditunjukan pada beberapa penyelesaian di bawah ini :

1. TOPSIS dimulai dengan membangun sebuah matriks keputusan. Pada matriks keputusan, kolom matriks menyatakan atribut yaitu kriteria-kriteria yang ada, sedangkan baris matriks menyatakan alternatif yaitu nama mobil yang akan dibandingkan dan tipe kriteria adalah benefit. Matrik keputusan dapat dilihat pada tabel di bawah ini.

Di bawah ini merupakan bobot dari beberapa kriteria harga sewa mobil yang terdiri dari (Rp.500.000,-/hari), (Rp.450.000,-/hari), (Rp.400.000,-/hari), (Rp.350.000,-/hari), (Rp.300.000,/hari).

Tabel 2. Bobot Kriteria Harga Sewa

\begin{tabular}{|c|c|}
\hline $\begin{array}{c}\text { Kriteria Luas } \\
\text { Tanah }\end{array}$ & Bobot \\
\hline Rp. 500.00,-/hari & 2 \\
\hline Rp. 450.00,-/hari & 4 \\
\hline Rp. 400.00,-/hari & 3 \\
\hline
\end{tabular}




\begin{tabular}{|l|l|}
\hline Rp. 350.00,-/hari & 1 \\
\hline Rp. 300.00,-/hari & 5 \\
\hline
\end{tabular}

Di bawah ini merupakan bobot dari kriteria bahan bakar seperti Pertamax, Premium, Solar, Bio Solar. Bobot kriteria dapat dilihat pada tabel di bawah ini:

Tabel 3. Bobot Kriteria Bahan Bakar

\begin{tabular}{|c|c|}
\hline Kriteria Bahan Bakar & Bobot \\
\hline Pertamax & 5 \\
\hline Premium & 4 \\
\hline Solar & 1 \\
\hline Bio Solar & 3 \\
\hline
\end{tabular}

Di bawah ini merupakan bobot dari kriteria kenyamanan seperti Kondidi mesin, Kondisi Fisik, Fasilitas Audio, Supir yang berpengalaman, Sempit. Bobot kriteria dapat dilihat pada tabel di bawah ini :

Tabel 4. Bobot Kriteria Kenyamanan

\begin{tabular}{|c|c|}
\hline Kriteria Kenyamanan & Bobot \\
\hline Kondidi Mesin & 5 \\
\hline Kondisi Fisik & 3 \\
\hline Fasilitas Audio & 2 \\
\hline $\begin{array}{c}\text { Supir yang } \\
\text { berpengalaman }\end{array}$ & 4 \\
\hline Sempit & 1 \\
\hline
\end{tabular}

Di bawah ini merupakan bobot dari kriteria kapasitas muatan seperti Ada (8-9 orang), (7-8 orang), (10-13 orang), (6-7 orang), dan (8-9 orang). Bobot kriteria dapat dilihat pada tabel di bawah ini :

Tabel 5. Bobot Kriteria Kapasitas Muatan

\begin{tabular}{|c|c|}
\hline $\begin{array}{c}\text { Kriteria Kapasitas } \\
\text { Muatan }\end{array}$ & Bobot \\
\hline 8-9 orang & 2 \\
\hline 7-8 orang & 3 \\
\hline 10-13 orang & 1 \\
\hline 6-7 orang & 4 \\
\hline 8-9 orang & 5 \\
\hline
\end{tabular}

Di bawah ini merupakan bobot dari kriteria tahun pembuatan seperti tahun 2015, 2014, 2013, 2012, 2000. Bobot kriteria dapat dilihat pada tabel di bawah ini:

Tabel 6. Bobot Tahun Pembuatan

\begin{tabular}{|c|c|}
\hline Kriteria Tahun Pembuatan & Bobot \\
\hline 2015 & 5 \\
\hline 2014 & 4 \\
\hline 2013 & 3 \\
\hline 2000 & 1 \\
\hline 2012 & 2 \\
\hline
\end{tabular}


Dari beberapa kriteria yang ada di atas, maka dilakukan sampel dalam pembobotan yang dimana mobil dilibatkan dalam membuat suatu matriks dalam penentuan rekomendasi pembelian perumahan.

Tabel 7. Matriks Keputusan

\begin{tabular}{|l|c|c|c|c|c|}
\hline \multicolumn{1}{|c|}{ Alternatif } & $\begin{array}{c}\text { Harg } \\
\text { a }\end{array}$ & $\begin{array}{c}\text { Bahan } \\
\text { Bakar }\end{array}$ & $\begin{array}{c}\text { Kenya } \\
\text { manan }\end{array}$ & $\begin{array}{c}\text { Kapasitas } \\
\text { Muaatan }\end{array}$ & $\begin{array}{c}\text { Tahun } \\
\text { Pembuatan }\end{array}$ \\
\hline YARIS 1.5 M/T & 5 & 5 & 5 & 2 & 5 \\
\hline KIJANG INOVA VA/T & 4 & 4 & 3 & 3 & 4 \\
\hline ALPHARD & 3 & 1 & 2 & 1 & 3 \\
\hline AGYA 1.0 E M/T & 2 & 3 & 4 & 4 & 2 \\
\hline AVANZA 1.3E M/T & 1 & 2 & 1 & 5 & 1 \\
\hline
\end{tabular}

2. Membuat matriks keputusan yang ternormalisasi

Setelah matriks keputusan dibangun, selanjutnya adalah membuat matriks keputusan yang ternormalisasi $\mathrm{R}$ yang elemen-elemennya ditentukan dengan rumus persamaan.

Untuk mencari nilai matriks keputusan ternormalisasi yaitu berdasarkan hasil perhitungan kolom matrik menyatakan atribut yaitu kriteria-kriteria yang ada dan baris matriks menyatakan alternatif yaitu nama perumahan sedangkan hasil perhitungan matriks keputusan ternormalisasi adalah sebagai berikut:

Tabel 8. Matriks Keputusan Ternormalisasi

\begin{tabular}{|l|c|c|c|c|c|}
\hline \multicolumn{1}{|c|}{ Alternatif } & Harga & $\begin{array}{c}\text { Bahan } \\
\text { bakar }\end{array}$ & $\begin{array}{c}\text { Kenya } \\
\text { manan }\end{array}$ & $\begin{array}{c}\text { Kapasit } \\
\text { as } \\
\text { Muatan }\end{array}$ & $\begin{array}{c}\text { Tahun } \\
\text { Pembuatan }\end{array}$ \\
\hline MOBIL YARIS 1.5 M/T & 0,674 & 0,674 & 0,640 & 0,629 & 0,674 \\
\hline MOBIL KIJANG INOVA VA/T & 0,451 & 0,539 & 0,384 & 0,405 & 0,539 \\
\hline MOBIL ALPHART & 0,404 & 0,134 & 0,256 & 0,134 & 0,404 \\
\hline MOBIL AGYA 1.0 E M/T & 0,269 & 0,409 & 0,512 & 0,539 & 0,629 \\
\hline MOBIL AVANZA 1.3 E M.T & 0,134 & 0,269 & 0,128 & 0,678 & 0,134 \\
\hline
\end{tabular}

3. Membuat matriks keputusan yang ternormalisasi terbobot

Setelah matriks keputusan ternormalisasi dibuat, selanjutnya adalah membuat matriks keputusan ternormalisasi terbobot. Pemisalan bobot yang dimasukkan untuk setiap kriteria adalah Harga sewa (20), Bahan Bakar (25), Kenyamanan (30), Kapasitas Muatan (15), dan Tahun Pembuatan (10) yang elemen - elemennya ditentukan dengan rumusan menggunakan 3.2. Sedangkan hasil perhitungan matriks keputusan ternormalisasi terbobot adalah sebagai berikut:

YARIS 1.5 M/T $=20 * 0,674=13,48$

$=25 * 0,674=16,85$

$=30 * 0,640=19,2$

$=15 * 0,629=9,435$

$=10 * 0,674=6,74$

KIJANG INOVA VA/T

$=20 * 0,451=9,02$

$=25 * 0,539=13,475$

$=30 * 0,384=11,52$

$=15 * 0,405=6,075$

$=10 * 0,539=5,39$ 


$$
\begin{aligned}
& \text { ALPHARD } \\
& =20 * 0,404=8,08 \\
& =25 * 0,134=3,35 \\
& =30 * 0,256=7,68 \\
& =15 * 0,134=2,01 \\
& =10 * 0,404=4,04
\end{aligned}
$$

\section{AGYA $1.0 \mathrm{E} \mathrm{M} / \mathrm{T}$}

$=20 * 0,269=5,38$

$=25 * 0,409=10,225$

$=30 * 0,512=15,36$

$=15 * 0,539=8,085$

$=10 * 0,629=6,29$

AVANZA 1.5E M/T

$=20 * 0,134=2,68$

$=25 * 0,629=15,725$

$=30 * 0,128=3,84$

$=15 * 0,678=10,17$

$=10 * 0,134=1,34$

Tabel 9. Matriks Keputusan Ternormalisasi Terbobot

\begin{tabular}{|l|c|c|c|c|c|}
\hline \multicolumn{1}{|c|}{ Alternatif } & Harga & $\begin{array}{c}\text { Bahan } \\
\text { bakar }\end{array}$ & $\begin{array}{c}\text { Kenya } \\
\text { manan }\end{array}$ & $\begin{array}{c}\text { Kapasi } \\
\text { tas } \\
\text { Muatan }\end{array}$ & $\begin{array}{c}\text { Tahun } \\
\text { Pembuat } \\
\text { an }\end{array}$ \\
\hline MOBIL YARIS 1.5 M/T & 13,48 & 16,68 & 19,2 & 9,435 & 6,74 \\
\hline MOBIL KIJANG INOVA VA/T & 9,02 & 13,475 & 11,52 & 6,075 & 5,39 \\
\hline MOBIL ALPHARD & 8,08 & 3,35 & 7,68 & 2,01 & 4,04 \\
\hline MOBIL AGYA 1.0 E M/T & 5,38 & 10,225 & 15,36 & 8,085 & 6,29 \\
\hline MOBIL AVANZA 1.3 E M.T & 2,68 & 15,725 & 3,84 & 10,17 & 1,34 \\
\hline
\end{tabular}

4. Menentukan matriks solusi ideal positif dan solusi ideal negatif

Selanjutnya menentukan matriks solusi ideal positif $\left(\mathrm{A}^{+}\right)$yang merupakan benefit criteria, untuk mencari nilai ideal positif yaitu dengan cara menentukan nilai tertinggi untuk setiap kriteria dan solusi ideal negatif ( $\left.\mathrm{A}^{-}\right)$yang merupakan cost criteria dengan cara mencari nilai terendah untuk setiap kriteria. Penentuan matriks solusi ideal positif dan negatif ditentukan dengan rumus menggunakan persamaan 3.3 dan 3.4.

Sedangkan hasil perhitungan matriks solusi ideal positif adalah sebagai berikut:

$$
\begin{array}{lll}
y_{1}^{+}=\operatorname{Max}\{13,48 ; 16,85 ; 19,2 ; 9,435 ; 6,74\} & =19,2 \\
y_{2}^{+}=\operatorname{Max}\{9,02 ; 13,475 ; 11,52 ; 6,075 ; 5,39\} & =13,475 \\
y_{3}^{+}=\operatorname{Max}\{8,08 ; 3,35 ; 7,68 ; 2,01 ; 4,04\} & =8,08 \\
y_{4}^{+}=\operatorname{Max}\{5,38 ; 10,225 ; 15,36 ; 8,805 ; 6,29\} & =10,225 \\
y_{5}^{+}=\operatorname{Max}\{2,68 ; 15,727 ; 3,84 ; 10,17 ; 1,34\} & =15,727 \\
A^{+}=\{19,2 ; 13,475 ; 8,08 ; 10,225 ; 15,727\} &
\end{array}
$$

Tabel 10. Solusi Ideal Positif

\begin{tabular}{|c|c|c|c|c|c|}
\hline $\begin{array}{c}\text { Solusi Ideal } \\
\text { Negatif }\end{array}$ & $\begin{array}{c}\text { Harga } \\
\text { Sewa }\end{array}$ & $\begin{array}{c}\text { Bahan } \\
\text { Bakar }\end{array}$ & $\begin{array}{c}\text { Kenya } \\
\text { manan }\end{array}$ & $\begin{array}{c}\text { Kapasitas } \\
\text { Muatan }\end{array}$ & $\begin{array}{c}\text { Tahun } \\
\text { Pembuatan }\end{array}$ \\
\hline
\end{tabular}




\begin{tabular}{|l|l|l|l|l|l|}
\hline $\mathrm{A}^{+}$ & 19,2 & 13,475 & 8,08 & 10,225 & 15,727 \\
\hline
\end{tabular}

Untuk perhitungan matriks solusi ideal negatif adalah sebagai berikut:

$$
\begin{array}{cl}
y_{1}^{-}=\operatorname{Max}\{13,48 ; 16,85 ; 19,2 ; 6,29 ; 6,74\} & =6,29 \\
y_{2}^{-}=\operatorname{Max}\{9,02 ; 13,475 ; 11,52 ; 4,05 ; 5,39\} & =4,05 \\
\operatorname{Max}\{8,08 ; 3,35 ; 7,68 ; 1.34 ; 4,04\} & =1,34 \\
y_{4}^{-}=\operatorname{Max}\{5,38 ; 10,225 ; 15,36 ; 5,39 ; 6,29\} & =5,38 \\
y_{5}^{-}=\operatorname{Max}\{2,68 ; 15,727 ; 3,84 ; 6,78 ; 1,34\} & =1,34
\end{array}
$$

$\mathrm{A}^{-}=\{6,29 ; 4,05 ; 1,34 ; 5,38 ; 1,34\}$

Tabel 11. Solusi Ideal Negatif

\begin{tabular}{|c|c|c|c|c|c|}
\hline $\begin{array}{c}\text { Solusi Ideal } \\
\text { Negatif }\end{array}$ & $\begin{array}{c}\text { Harga } \\
\text { Sewa }\end{array}$ & $\begin{array}{c}\text { Bahan } \\
\text { Bakar }\end{array}$ & $\begin{array}{c}\text { Kenya } \\
\text { manan }\end{array}$ & Kapasitas Muatan & $\begin{array}{c}\text { Tahun } \\
\text { Pembuatan }\end{array}$ \\
\hline $\mathrm{A}^{-}$ & 6,29 & 4,05 & 1,34 & 5,38 & 1,38 \\
\hline
\end{tabular}

5. Selanjutnya menghitung jarak alternatif dari solusi ideal positif $\left(\mathrm{D}^{+}\right)$dan jarak alternatif dari solusi ideal negatif $\left(\mathrm{D}^{-}\right)$yang ditentukan dengan rumus menggunakan persamaan 3.5. Sedangkan hasil menghitung separasi positif dan negetif adalah sebagai berikut:

$$
\begin{aligned}
& \text { Separasi Positif } \\
& \text { YARIS } \\
& \mathrm{D}_{1}^{+}=\sqrt{\left((13,48-19,2)^{2}+(16,85-13,475)^{2}+(19,2-8,08)^{2}+(6,29-10,225)^{2}+(6,74-15,727)^{2}\right.} \\
& \mathrm{D}_{1}^{+}=\sqrt{(-5,72)^{2}+(3,375)^{2}+(788,8)^{2}+(3,935)^{2}+(-8,987)^{2}} \\
& \mathrm{D}_{1}^{+}=\sqrt{32,718+11_{s} 390+62,220+15,484+80,766} \\
& \mathrm{D}_{1}^{+}=\sqrt{202,578} \\
& \mathrm{D}_{1}^{+}=14,232
\end{aligned}
$$

\section{KIJANG INOVA VA/T}

$$
\begin{aligned}
& \mathrm{D}_{2}^{+}=\sqrt{(9,02-19,2)^{2}+(13,475-13,475)^{2}+(11,52-8,08)^{2}+(4,05-10,225)^{2}+(5,39-15,727)^{2}} \\
& \mathrm{D}_{2}^{+}=\sqrt{(-10,18)^{2}+(0)^{2}+(3,44)^{2}+(-6,175)^{2}+(-10,337)^{2}} \\
& \mathrm{D}_{2}^{+}=\sqrt{-5.5225+0+(-22,3729)+0+0} \\
& \mathrm{D}_{2}^{+}=\sqrt{-32,5525} \\
& \mathrm{D}_{2}^{+}=5,7055
\end{aligned}
$$

\section{ALPHARD}

$D_{3}^{+}=\sqrt{(8,08-19,2)^{2}+(3,35-13,475)^{2}+(7,68-8,08)^{2}+(1,34-10,225)^{2}+(4,04-15,727)^{2}}$

$D_{3}^{+}=\sqrt{(-11,12)^{2}+(-10,125)^{2}+(-0,4)^{2}+(-8,885)^{2}+(-11,687)^{2}}$

$\mathrm{D}_{\mathrm{a}}^{+}=\sqrt{123,654+(-102,515)+(-0,16)+78,943+136,585}$

$\mathrm{D}_{\mathrm{a}}^{+}=\sqrt{236,507}$

$\mathrm{D}_{\mathrm{a}}^{+}=15,378$

\section{AGYA 1.0 E M/T}

$\mathrm{D}_{4}^{+}=(5,38-19,2)^{2}+(10,225-13,475)^{2}+(15,36-8,08)^{2}+(5,39-10,225)^{2}+(6,29-15,727)^{2}$

$\mathrm{D}_{4}^{+}=\sqrt{(-13,82)^{2}+(-3,475)^{2}+(7,28)^{2}+(-4,835)^{2}+(-9,437)^{2}}$

$\mathrm{D}_{4}^{+}=\sqrt{(-190,99)+12,0756+52,998+23,377+(-18,874)}$

$\mathrm{D}_{4}^{+}=\sqrt{121,413}$ 
AVANZA 1.3 E M/T

$\mathrm{D}_{\mathrm{s}}^{+}=\sqrt{(2,68-19,2)^{2}+(15,725-13,475)^{2}+(3,84-8,08)^{2}+(6,78-10,225)^{2}+(1,34-15,727)^{2}}$

$\mathrm{D}_{5}^{+}=\sqrt{(-16,52)^{2}+(2,25)^{2}+(12,5)^{2}+(-4,24)^{2}+(-14,387)^{2}}$

$\mathrm{D}_{5}^{+}=\sqrt{\left(-33_{\imath}, 04\right)+5,0625+156.25+8,48+(-28,774)}$

$\mathrm{D}_{5}^{+}=\sqrt{107,97}$

$\mathrm{D}_{5}^{+}=10,390$

Tabel 12. Seperasi Positif

\begin{tabular}{|l|c|}
\hline \multicolumn{1}{|c|}{ Alternatif } & D $^{+}$ \\
\hline MOBIL YARIS 1.5 M/T & 14,232 \\
\hline MOBIL KIJANG INOVA VA/T & 5,7055 \\
\hline MOBIL ALPHARD & 15,378 \\
\hline MOBIL AGYA 1.0 E M/T & 11,018 \\
\hline MOBIL AVANZA 1.3 E M/T & 10,390 \\
\hline
\end{tabular}

\section{Separasi Negatif}

YARIS 1.5 M/T

$D_{1}^{-}=\sqrt{(13,48-62,9)^{2}+(16,85-4,05)^{2}+(19,2-1,34)^{2}+(6,29-5,38)^{2}+(6,74-2,68)^{2}}$

$\mathrm{D}_{1}^{-}=\sqrt{(7,19)^{2}+(12,8)^{2}+(17,86)^{2}+(0,91)^{2}+(4,06)^{2}}$

$\mathrm{D}_{1}^{-}=\sqrt{51_{2} 6961+0+191_{s} 7104+0+0}$

$\mathrm{D}_{1}^{-}=\sqrt{243,406}$

$\mathrm{D}_{1}^{-}=15,601$

KIJANG INOVA VA/T

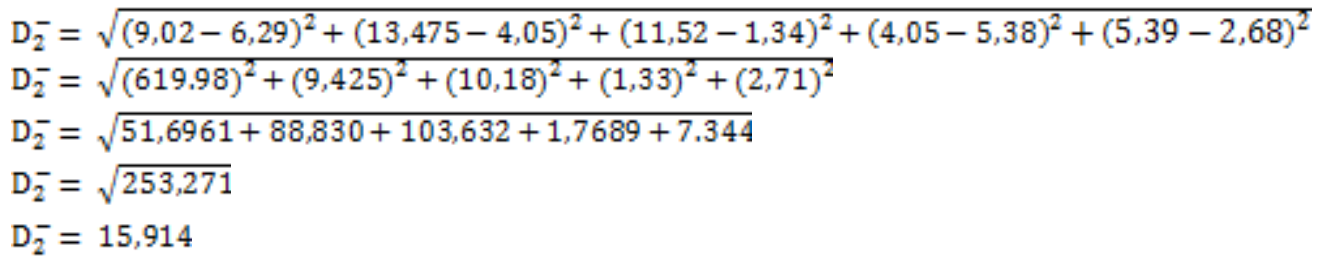

\section{ALPHARD}

$D_{3}^{-}=\sqrt{(8,08-6,29)^{2}+(3,35-4,05)^{2}+(7,68-1,34)^{2}+(1,34-5,38)^{2}+(4,04-2,68)^{2}}$

$\mathrm{D}_{\mathrm{a}}^{-}=\sqrt{(1,79)^{2}+(-0,7)^{2}+(6.34)^{2}+(-4,04)^{2}+(1,3)^{2}}$

$\mathrm{D}_{\mathrm{a}}^{-}=\sqrt{3,2041+-0,49+40,1956+16,3216+1,69}$

$\mathrm{D}_{\mathrm{a}}^{-}=\sqrt{60,9213}$

$\mathrm{D}_{\mathrm{a}}^{-}=7,8052$

\section{AGYA 1.0 E M/T}

$D_{4}^{-}=\sqrt{(5,38-6,29)^{2}+(10,225-4,05)^{2}+(15,36-1,34)^{2}+(5,39-5,38)^{2}+(6,29-2,66)^{2}}$

$\mathrm{D}_{4}^{-}=\sqrt{(-1,52)^{2}+(5,95)^{2}+(14,02)^{2}+(0,01)^{2}+(3,61)^{2}}$

$\mathrm{D}_{4}^{-}=\sqrt{\left(-3 x_{s} 04\right)+35,4025+196,5604+0,0001+13_{s} 0321}$

$\mathrm{D}_{4}^{-}=\sqrt{241,955}$

$\mathrm{D}_{4}^{-}=15,554$

\section{AVANZA 1.3 E M/T}

Sistem Pendukung Keputusan Pemilihan Mobil Rental dengan Menggunakan Metode 


$$
\begin{aligned}
& D_{5}^{-}=\sqrt{(2,68-6,29)^{2}+(15,725-4,05)^{2}+(13,84-1,34)^{2}+(6,78-5,38)^{2}+(1,34-2,68)^{2}} \\
& D_{5}^{-}=\sqrt{(-3,61)^{2}+\left(11_{\imath}, 675\right)^{2}+(12,5)^{2}+(1,4)^{2}+(-1,34)^{2}} \\
& D_{5}^{-}=\sqrt{(-13,0321)+136,3056+156,25+1,54+1,7956} \\
& D_{5}^{-}=\sqrt{282,8591} \\
& D_{5}^{-}=16,818
\end{aligned}
$$

Tabel 13. Seperasi Negatif

\begin{tabular}{|l|c|}
\hline \multicolumn{1}{|c|}{ Alternatif } & D $^{-}$ \\
\hline MOBIL YARIS 1.5 M/T & 15,601 \\
\hline MOBIL KIJANG INOVA VA/T & 15,914 \\
\hline MOBIL ALPHARD & 7,8052 \\
\hline MOBIL AGYA 1.0 E M/T & 15,554 \\
\hline MOBIL AVANZA 1.3 E M/T & 16,818 \\
\hline
\end{tabular}

6. Menghitung kedekatan relative terhadap solusi ideal positif

Setelah menghitung jarak alternatif dari solusi ideal positif $\left(\mathrm{D}^{+}\right)$dan jarak alternatif dari solusi ideal negatif $\left(\mathrm{D}^{-}\right)$, selanjutnya adalah menghitung kedekatan relatif terhadap solusi ideal positif dengan rumus menggunakan persamaan (3.7). Sedangkan hasil perhitungan kedekatan relatif terhadap solusi ideal positif adalah sebagai berikut :

a. YARIS $1.5 \mathrm{M} / \mathrm{T}$

$$
\begin{aligned}
V_{1} & =\frac{15,601}{(15,601+14,232)} \\
V_{1} & =\frac{15,601}{29,833} \\
V_{1} & =0,5229
\end{aligned}
$$

\section{b. KIJANG INOVA VA/T}

$$
\begin{aligned}
& V_{2}=\frac{15,914}{(15,914+5,7055)} \\
& V_{2}=\frac{15,914}{21,6195} \\
& V_{2}=0,7360
\end{aligned}
$$

\section{c. ALPHARD}

$$
\begin{aligned}
& V_{3}=\frac{7,8025}{(7,8025+15,378)} \\
& V_{3}=\frac{7,8025}{23,1805} \\
& V_{3}=0,3365
\end{aligned}
$$

d. AGYA 1.0 E M/T

$$
\begin{aligned}
V_{4} & =\frac{15,554}{(15,554+11,018)} \\
V_{4} & =\frac{15,554}{26,572} \\
V_{4} & =0,5853
\end{aligned}
$$




$$
\begin{aligned}
& \text { e. AVANZA 1.3 E M.T } \\
& V_{5}=\frac{16,818}{(16,818+10,390)} \\
& V_{5}=\frac{16,818}{27,208} \\
& V_{5}=0,6181
\end{aligned}
$$

Tabel 14. Nilai V

\begin{tabular}{|l|c|}
\hline \multicolumn{1}{|c|}{ Alternatif } & V \\
\hline MOBIL YARIS 1.5 M/T & 0,5229 \\
\hline MOBIL KIJANG INOVA VA/T & 0,7360 \\
\hline MOBIL ALPHARD & 0,3365 \\
\hline MOBIL AGYA 1.0 E M/T & 0,5853 \\
\hline MOBIL AVANZA 1.3 E M/T & 0,6181 \\
\hline
\end{tabular}

\section{Merangking Alternatif}

Berikutnya alternatif diurutkan dari nilai $\mathrm{V}$ terbesar ke nilai $\mathrm{V}$ terkecil. Alternatif dengan nilai $\mathrm{V}$ terbesar merupakan solusi yang terbaik.

Tabel 15. Pengurutan Alternatif

\begin{tabular}{|l|c|}
\hline \multicolumn{1}{|c|}{ Alternatif } & V \\
\hline MOBIL KIJANG INOVA VA/T & 0,7360 \\
\hline MOBIL AVANZA 1.3 E M/T & 0,6181 \\
\hline MOBIL AGYA 1.0 E M/T & 0,5853 \\
\hline MOBIL YARIS 1.5 M/T & 0,5292 \\
\hline MOBIL ALPHARD & 0,3365 \\
\hline
\end{tabular}

Pada tabel 15., dapat dilihat bahwa alternatif yang menempati uturan pertama yaitu, Mobil Kijang Inova VA/T dengan bobot 0,7360 , alternatif yang menempati urutan kedua, yaitu Mobil Avanza 1.3E M/T dengan bobot 0,6181, alternatif yang menempati urutan ketiga, yaitu Mobil Agya $1.0 \mathrm{E} \mathrm{M} / \mathrm{T}$ dengan bobot 0,5853 . Alternatif yang menempati urutan keempat, yaitu Mobil Yaris 1.5 M/T dengan bobot 0,5292, dan alternatif yang menempati urutan kelima, yaitu Mobil Alphard dengan bobot 0,3365 . Berdasarkan hasil pengurutan, maka pilihan terbaik yang menjadi solusi untuk pemilihan Mobil Rental, yaitu Mobil Kijang Inova VA/T.

\section{KESIMPULAN}

Berdasarkan hasil penelitian yang penulis lakukan mengenai sistem pendukung keputusan pemilihan mobil rental dengan menggunakan metode topsis berdasarkan penilaian kriteria setiap jenis mobil rental pada perusahaan, penulis dapat menarik kesimpulan sebagai berikut :

1. Pemberian kriteria dalam proses pemilihan mobil rental dapat membantu dalam mengambil keputusan untuk menentukan jenis mobil yang sesuai dengan keinginan penyewa. Dengan kriteria sebagai berikut : Harga Sewa Mobil, Bahan Bakar, Kenyamanan, Kapasitas Muatan, Tahun Pembuatan.

2. Sistem yang dibangun dapat menjadi bahan pertimbangan oleh pengguna untuk dapat membantu dalam proses pengambilan keputusan saat akan memilih mobil rental. 


\section{DAFTAR PUSTAKA}

[1] H. Zakaria, "Perancangan Aplikasi Penjualan dan Penyewaan Mobil berbasis Web menggunakan Model Waterfall pada CV. Dhiyara Anugrah," J. Inform. Universtias Pamulang, vol. 2, no. 4, pp. 184-180, 2017.

[2] A. Kurniawan, A. A. Nugroho, and S. Mulyono, "Sistem Informasi Rental Mobil Terintegrasi Menggunakan Service Oriented Architecture," TRANSISTOR Elektro dan Inform., vol. 2, no. 2, pp. 134-142, 2018, [Online]. Available: http://jurnal.unissula.ac.id/index.php/EI/article/view/3053/2216.

[3] T. Limbong et al., Sistem Pendukung Keputusan: Metode dan Implementasi. Medan: Yayasan Kita Menulis, 2020.

[4] K. Siregar and E. R. Siagian, "Implementasi Metode Technique for Order Preference by Similarity to Ideal Solution dalam Pemilihan Jenis Kerang Konsumsi," MEANS (Media Inf. Anal. dan Sist., vol. 3, no. 2, 2018.

[5] S. Mallu, "Sistem pendukung keputusan penentuan karyawan kontrak menjadi karyawan tetap menggunakan metode topsis," J. Ilm. Teknol. dan Inf. Terap., vol. 1, no. 2, pp. 36-42, 2015.

[6] U. Salamah and G. A. Rusady, "Perancangan Aplikasi Rental Mobil,” Igarss 2019, vol. 8, no. 1, pp. 1-5, 2019.

[7] Kusrini, Konsep dan Aplikasi Sistem Pendukung Keputusan. 2007.

[8] S. Kusrini, "Sistem Pakar Teori dan Aplikasi," Penerbit Andi Yogyakarta, 2006.

[9] T. Limbong et al., Sistem Pendukung Keputusan: Metode \& Implementasi. Yayasan Kita Menulis, 2020.

[10] Paska Marto Hasugian, "FUZZY MULTIPLE ATTRIBUTE DECISION MAKING UNTUK MENENTUKAN TENAGA KERJA DENGAN METODE SIMPLE ADDITIVE WEIGHITNG (STUDI KASUS : PT CAHAYA BINTANG MEDAN)," Pelita Inform. Budi Darma, 2012.

[11] A. Kurniawan, "Implementasi Metode Topsis Pada Sistem Pendukung Keputusan Seleksi Penerimaan Beasiswa (Studi Kasus : Stkip Pgri Nganjuk),” May 2013.

[12] I. Muzakkir, "Penerapan Metode Topsis untuk Sistem Pendukung Keputusan Penentuan Keluarga Miskin pada Desa Panca Karsa II,” Ilk. J. Ilm., vol. 9, no. 3, pp. 274-281, 2017.

[13] P. A. W. Santiary, P. I. Ciptayani, N. G. A. P. H. Saptarini, and I. K. Swardika, "Sistem Pendukung Keputusan Penentuan Lokasi Wisata dengan Metode Topsis," J. Teknol. Inf. dan Ilmu Komput., vol. 5, no. 5, p. 621, Oct. 2018, doi: 10.25126/jtiik.2018551120. 